\title{
The Pursuit of Inclusion in Unequal Contemporary Cities. Learning from Cape Town Desegregation
}

\author{
Miriam Bodino
}

ABSTRACT - One of the greatest challenges of contemporary cities is to engage with their emerging inequality. This research argues that public spaces play a key role in contrasting the process of this growing marginalization. The objective of this paper is to determine whether it is possible to contrast the spatial disparity within the contemporary cities, through the design of more "just" and inclusive spaces.

In the past two decades South Africa has been the subject of many studies regarding inequality and segregation, because of its entrenched history of apartheid and its severe imbalanced income distribution. The desegregation process of Cape Town has been attempting to use public space as social infrastructure to bridge its divide. Firstly, the shift towards a more inclusive city happened in academic writing. Secondly, the shift also occurs in municipal public space programmes. And lastly, the shift materialized in several innovative projects, which have been carried out mainly in township areas. Through the analysis of this progression, it is possible to delineate some visible improvements - punctual but fundamental steps towards a "city for all."

Keywords: social segregation, spatial injustice, post-apartheid, municipal policies, rainbow South Africa

The last decades have seen an increased interest in development processes worldwide, starting from the UN Millennium Development Goals (MDG) to the most recent UN Sustainable Development Goals (SDG). 
Poverty has always existed, but thanks to the MDG, it has been treated as a global issue. The amount of goals has increased from eight in MDG to seventeen in SDG. This demonstrates the complexity of the international issues, and the determination to find as well as to measure the appropriate indicators. The tenth goal of the UN Agenda 2030 has been defined as:

Reduce inequality within and among counties.

While income inequality between countries may have been reduced, inequality within countries has risen. There is growing consensus that economic growth is not sufficient to reduce poverty if it is not inclusive and if it does not involve the three dimensions of sustainable development - economic, social and environmental. To reduce inequality, policies should be universal in principle paying attention to the needs of disadvantaged and marginalized populations. ${ }^{1}$

In other words, although the Gross Domestic Product growth has been achieved in many countries, the benefits of this progress have not been distributed homogeneously. One of the simplistic consequences has been to create "growth" instead of real development. Of course, the understanding of the relation between growth and development is not an easy challenge. Hence, it involves the definition of development, the beneficiaries of development, and the policies that can implement as well as to put these developments into practice. The economic sector cannot be ignored in our globalized economy, but the economic indicators are not enough to represent the complex social, cultural, spatial and economic reality (as stated in the UN Goal n.10). This research assumes that the focus on the wrong indicator - or at one indicator alone - could mislead the find of effective solutions. Therefore, an inclusive approach is mandatory when analysing the contemporary cities.

The diagram of the world income distribution by the economist Yuri Dikhanov shows that:

the richest fifth of the world's population have three-fourths $(74.1 \%)$ of the world's entire income, while the poorest fifth of the world's population have only $1.5 \%$ of the world's income. ${ }^{2}$

It is not by chance that the Sub-Saharan Africa region is mainly represented by the poorest percentile. At the same time, it is useful to look at the Gini coefficient, which is considered as the standard economic measure of income inequality. It represents the income distribution for the residents of a nation. Consequently, the analysis of the Gini index by the World Bank ${ }^{3}$ may help to understand better the existing economical contrast within some countries. According to the last estimate, South Africa has the highest levels of income inequality therefore it can be considered as an extreme case study - by considering the economic indicator. 
Looking at the global scale - since more than 50 percent of the world population currently lives in cities and the major increase in urban population is happening in developing countries - the focus on urban inequality have shown an increased interest between scholars. This research claims that spatiality has a fundamental role in the process. As a matter of fact, the built environment and the city context - first of all public spaces - have a key role in helping or contrasting this process of growing marginalization. Therefore, one of the greatest challenges of contemporary cities is to engage with the emerging inequality. The objective of this paper is to determine whether it is possible to contrast the spatial disparity within the contemporary cities, through the design of more "just" and inclusive spaces.

\section{Spatial and Social Impact}

Investigating the spatial aspect of inequality - instead of focusing only on economic ones - is the starting point of this research. Indeed, the design of spatiality includes consideration of social, cultural, environmental and also economic aspects. It is more complex and inclusive, but also closer to reality.

The chosen case study is South Africa, where the spatial inequality has been inherited by the apartheid. The apartheid has minutely planned the separation and the differentiation of races through the use of space. It is obvious that those spatial divisions had a huge social impact on the urban population. The social struggle, together with the political struggle, had the power to break the apartheid system in 1994. On one hand, the year 1994 embodies a radical shift and a formal rebirth; however, on the other hand:

it is not yet possible to conceive of the country without reflecting on apartheid. Apartheid and post-apartheid remain fundamentally linked. ${ }^{4}$

The term post-apartheid indicates not only the temporal period after the first democratic election held in 1994, but for many scholars it represents a process of transformation of South African cities, a process called "desegregation." Nelson Mandela first objective for his Country have been to create a "rainbow nation," 5 based on equality for all South African citizens, especially for the one previously discriminated. The implementation of this project is today struggling facing the reality.

\section{SEGREGATION IN CAPE TOWN, SOUTH AFRICA}

The uniqueness of South Africa has its roots in the colonial period. The first European settlers arrived in the Cape in 1652. The Dutch and the Britain shaped the settlement of Cape Town during that time, by applying European aesthetics and spatial traditions. 
From the establishment of Cape Town in 1652, a fully colonial world began to sprout. In the course of the following two hundred years, that world developed an important urban component. ${ }^{6}$

In this context, the public spaces were used as "places for trading and performing the dominant social order." ${ }^{7}$ After 1900, the modernization and the separation became more evident. The control over space to divide racial groups was intensified and formalized by the institution of apartheid, in 1948 (under the newly-elected Afrikaner National Party). The racial distinction existed since the first moment of colonization, even if many authors recognise the relatively "mix" of some Cape Town neighbourhood (District Six is one example). From 1948, the racial policies have been implemented and became increasingly severe as per the notorious "Group Areas Act provided for areas within the urban environment to be declared for the exclusive use of one particular racial group," such as the "White only" area.

People were only allowed to own or rent residential property or businesses in areas classified for their racial group. Unlike previous acts, which proclaimed new areas for particular races, the Group Areas Act was also retrospective in its planning. It allowed for the rezoning of existing residential and business areas for particular race groups. ${ }^{8}$

Hence, the major noticeable result of the Group Areas Act has been the great demolition of existing neighbourhoods or portion of urban areas mainly located in the inner city and in well-located districts - to host the new "White only" areas. The consequent evictions of local residents have been remedied by planning and building of townships divided by racial groups (Coloured, Indian, and black African). Compared to the "White only" areas, the townships were distinguished by their lack of public spaces and institutions. The organization of the space was structured with a great influence of modernization, and with the specific intention of "control (to access easy access for military tanks) and to discourage social interaction." 9 The urban environment has changed a lot due to a growing process of privatization. ${ }^{10}$ Moreover, there has been an increase construction of highways and road infrastructures, which are connected with the rising use of private cars.

In this context, the places of encounter and opportunity for relations between social and racial groups were "either eliminated or highly regulated and divided." 11

The spatial segregation worked as social segregation - as scheduled (Fig. 1).

As mentioned earlier, the election of Nelson Mandela represented a memorable point of shift and an opportunity to transform the apartheid segregation into South African integration. This transformation brings huge challenges. The impact of its history is still very visible in Cape Town, even if many attempts have been done during the post-apartheid period. There 


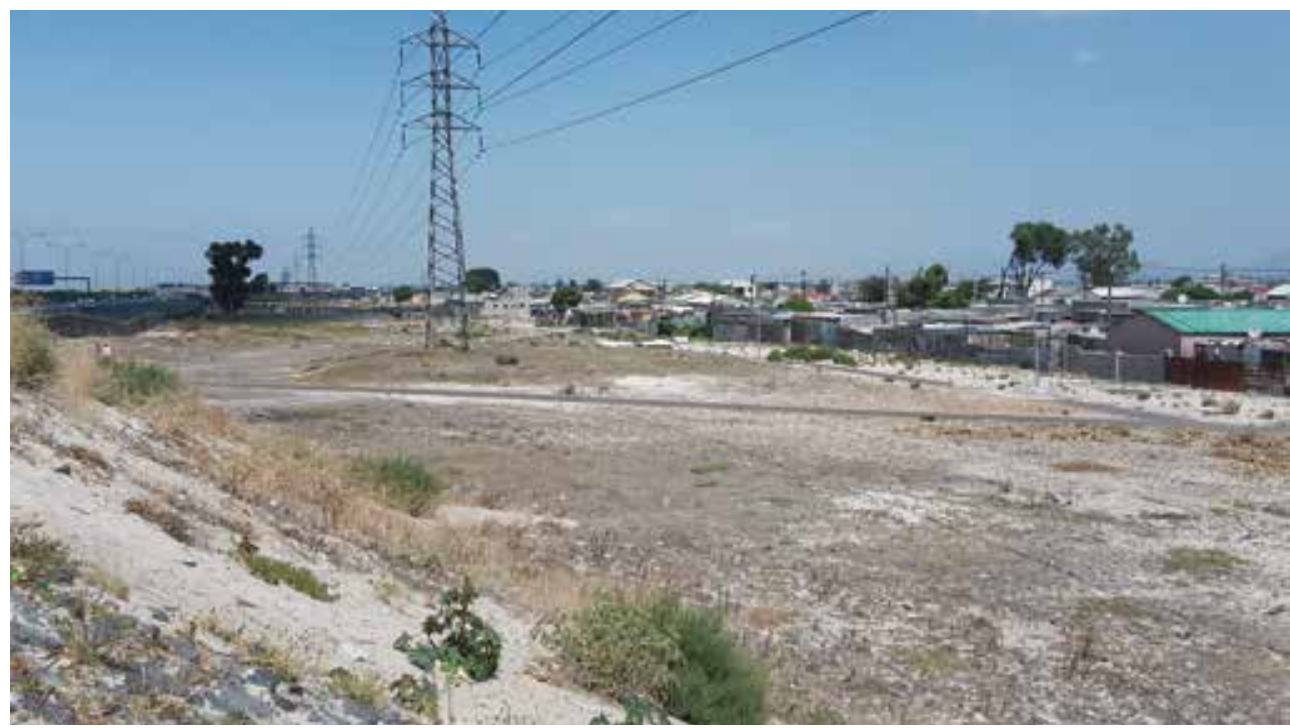

Figure 1. This photo shows how roads are used as means of separation, in which crossing is not easy and even dangerous. As a matter of fact, highways and overhead power lines have been used to divide racial groups and to control entry or exit points of settlements.

are evidences of the ongoing process of desegregation. These evidence can be traced from the 1990s through the analysis of three main elements: firstly, the publication of articles and books; secondly, the changing policies about public spaces, and thirdly, some innovative projects carried out mainly in the township areas. Such evidences might serve as markers of movements towards inclusivity.

\section{DESEGREGATION: PUBLIC SPACE POTENTIAL}

By introducing this paragraph, it is important to clarify the following words and their definition in the research context: desegregation, integration, public space and inclusion are then briefly described.

The word desegregation refers to the attempts to "rebuild the apartheid city into its antithesis: the integrated city." ${ }^{12}$ This desegregation process in Cape Town has been attempting to use public space as the social infrastructure to connect urban fragmentation. Hence, spatial integration has been the goal to be achieved through urban policies. Public spaces are here indented as social, cultural, economic and political infrastructure of the city. They can include public buildings, open areas, but also streets and places to gather, meet and interact, where people affirm their shared rights to the city. They can be labelled as private or public. Public spaces are where urban life is being made. They are promoted by the City, planned by architects and planners, and used by the local communities. The South Africa government is encouraging a vision for open, integrated and inclusive public spaces. Inclusion means that no one has to be excluded, that everyone has the right to access to those spaces; and therefore potentially create the integrated city. 
It is not possible to fill the significant gap of income inequality with the creation of inclusive public spaces. However, in the South African context, the planning - and place-making - of vibrant and sustainable public elements can provide the long-term infrastructure to improve the quality of life of the poorest and therefore to reduce the spatial inequalities.

In the past two decades South Africa has been the subject of many studies regarding inequality and segregation, because of its entrenched history of apartheid and its severe imbalanced income distribution. By looking at scholars and researchers' rising interest in South African transformation, it is possible to define a brief list of progress achieved. Architects and planners started in the 1990s to see public space as the means through which promote social and spatial connection. In other words, the use "public space to bridge divides" ${ }^{13}$ has become the objective of Cape Town transformation. Firstly, this shift happened in academic writing; secondly, in municipal public space programmes; lastly, the shift materialized in several innovative projects carried out in, but not only, the township areas.

\section{Academic Shift}

The Municipal Spatial Development Framework of Cape Town (called MuniSDF) assumed as major city problems:

- the poor quality of the urban public spatial environment

- the sprawl generated by the planning around the use of private cars

- the low density

- the considerable distances between poor peripheries and the city centre.

The objective of the framework was "to built a city that works for all." ${ }^{14}$ This vision of the future was developed by Prof. David Dewar, hired in 1997 by the City of Cape Town metropolitan government to lead the MuniSDF. The innovative planning approach established the following determining issues: "integration, equity, redistribution and quality of life." ${ }^{15}$ The draft was published in 1999 and it is still considered a fundamental document in understanding the post-apartheid shift. The framework underlined the unequal distribution of "interchanges" and "centres" of the city. Therefore, the proposal focused on integration modes, promotion of activity spines or corridors, resolution of functional conflicts, creation of key pedestrian links and attention to railway system. ${ }^{16}$ Within this context, political and academic attention started to see in public spaces the potential to sew apartheid spatial and social's wounds. The achievement of high-quality public space was considered as the heart of any positive approach to settlement making and urban management. Dewar affirmed the importance of public space as follows: 
Urban public spaces - streets, squares and promenades - are the most important form of social infrastructure in urban settlements: they act as "urban living rooms", especially for people living in over crowded conditions; they connect communities and inform people's "mental maps of the city." Public spaces are particularly important in the lives of poorer people, whose housing is often too small for household needs. ${ }^{17}$

Despite the meaning of public space having its origin in Western countries, the essence of public realms is the same. One of the inherent values of cities is to meet and increase opportunities through encounter: squares and public spaces have always been crucial all over the world to realize those expectations. At the same time, it is essential to recognize that "Western influence has directly (through colonization) or indirectly exported the concrete forms of European public space to many other parts of the world." ${ }^{18}$ In South Africa public spaces assumed a particular meaning during what we have called post-apartheid period. In 1991, Cape Town public spaces of the poorest areas are described by two University of Cape Town's prominent professors: David Dewar and Roelof Uytenbogaardt (in the book South African Cities. A Manifesto for Change), as inhospitable, dangerous, and frequently serving as dumping grounds for rubbish. Some of the important statements of the book can be considered revolutionary, especially considering that the apartheid regime was still ruling. ${ }^{19}$ Nevertheless, they became crucial in the imagination of the reconstruction programme proposed for the city. After the year 1994, the re-appropriation of some public spaces, banned during the apartheid to the "non-White" ethnics, represented the first step toward the building of a more inclusive country. As a matter of fact, public spaces are particularly relevant in an urban context because they are spaces for sharing and meeting. Consequently, they are inclusive by definition.

\section{Municipal Policies and Innovative Projects}

Since 1994 the City of Cape Town has addressed its planning approach to mediate between the world class city's ambition and pro-poor strategies. Globalization and capitalism have influenced the ongoing transformation process, often exacerbating already existing issues. Social and spatial polarization is a consequence of this dual ambition. On one hand, investments in city centres tried to attract foreign and private interests; and focused on the international image of the city. On the other hand, subsidized housing programmes and pro-poor strategies took place in the townships and suburbs. ${ }^{20}$ Accepting that "Cape Town's increasing global strength has not alleviated poverty or segregation in the city, and that the spoils of globalization have not been equally shared," ${ }^{21}$ this article focus its attention on the importance of new municipal policies and on the related projects of public spaces. 
The Spatial Planning and Urban Design department (SPUD) ${ }^{22}$ of the City of Cape Town became the reference city's office whose role of coordination, development and monitoring has been crucial. The department has been responsible for preparing the city-wide spatial development framework coordinating the other departments eventually involved. In 1996, the metropolitan area was still politically divided into six municipalities and the so called "Unicity" was created just in the year 2000. In this context, the integrated department of SPUD has been an important innovation.

In 1999, the first important programme of the urban design division started under the name of Dignified Places Programme (DPP), also called Dignified Public Space, managed by the urban designer Barbara Southworth.

The Programme to date has prioritized projects at such structurally and symbolically significant locations, where a public space intervention has the potential to integrate the city; promote accessibility or establish a new and positive sense of place. ${ }^{23}$

The redistribution of public spaces and the acupuncture approach concentrated a great amount of interventions in township or periphery areas. "Five principles have consistently guided the planning, design and implementation of the programme. These are equity, place-making, integration, minimalism and generation." ${ }^{24}$ Projects like Downs = Market Plaza in Manenberg, Philiippi Market Plaza, Philippi Station taxi and market plaza in Mitchells Plain, Manenberg Play park, Nyanga street markets \& bathhouse and Langa Cultural Precinct Public Square were completed in townships area. In the city centre Pier Place and Church Square have been redesigned also. The DPP ended officially in 2008. A new programme called Quality Public Spaces replaced DPP; it has been similar in content and it has lasted until 2011.

The Soccer World Cup in 2010 made the City concentrates its attention on the international event and on the city centre, where the majority of the tourists were hosted. The main event legacy projects have been: the Gran Parade restyle, a new stadium, the Fan Mile which linked the central business district and the soccer facilities; and the Green Point urban park. The great opportunity created by this event modelled the inner city into a global attraction. At the same time, it neglected - or even concealed - the urban poor. The N2 gateway project, for example, has been presented as a pioneering housing solution for informal inhabitants of Langa. In contrast, due to its strategic position, it can also be conceived as a camouflage to improve the urban view for foreigners when driving from the international airport to the city centre. When the international attention moved away, the city department started to evaluate the application of its programmes and the city commissioned a review report to external professionals. The aim of the report was to adjust the policies to better answer to the Cape Town's needs. The limited operational funding and the inadequate management and 

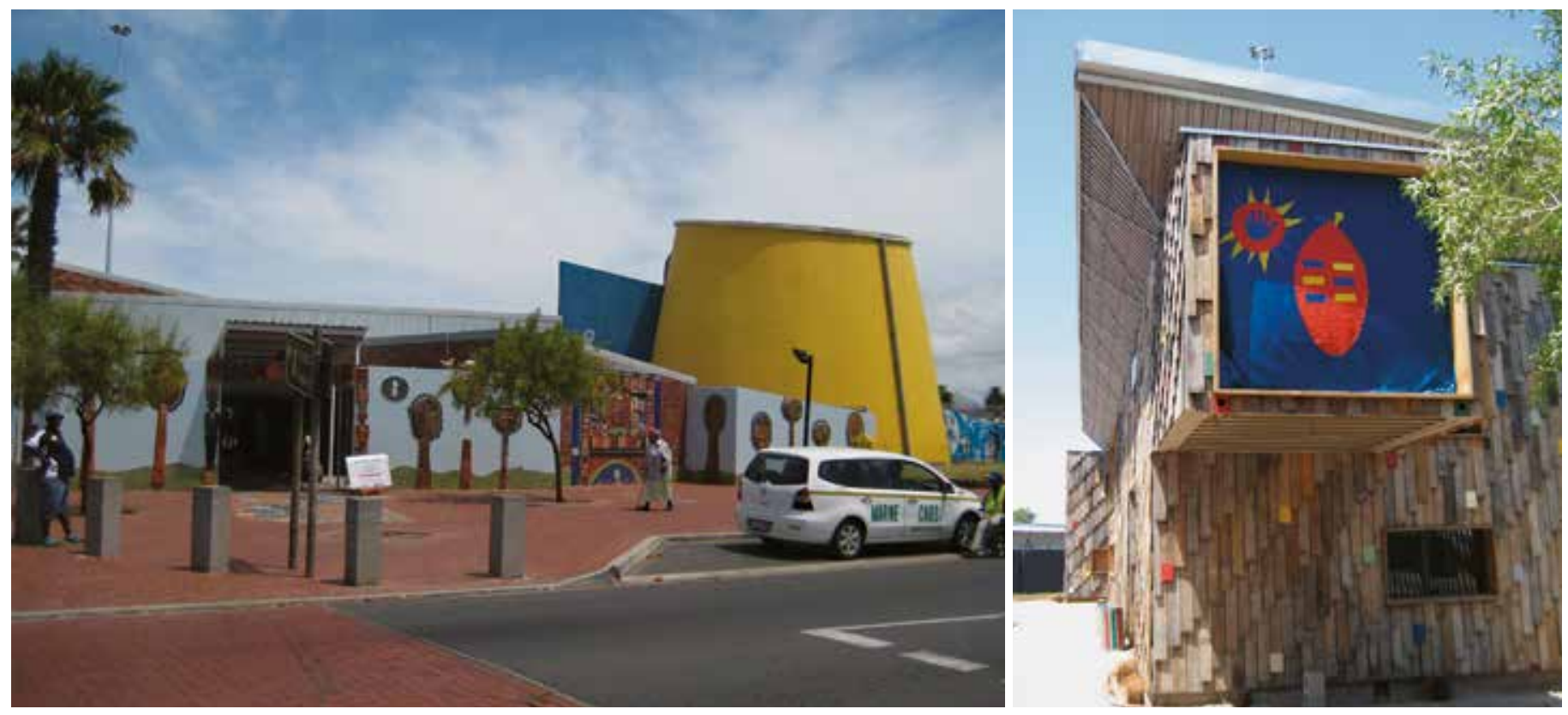

Figure 2. The photo on the left shows the Guga S'Thebe cultural centre's entrance. On the right, the new theatre.

maintenance capacity represented the main challenges to take into account.

In the same year, thanks to initiatives of non-governmental organizations, private associations and architects, some innovative projects have been built within the boundary of Cape Town and some experiments and innovations have been proposed in order to address the significant housing problem. Nevertheless, we will concentrate on the public facilities and spaces for encounter and inclusion completed in the last two decades. Some examples are presented below. The comprehensive understanding of each case study would require a much deeper analysis. And this is not the aim of this paper. The objective instead is to show that different and multiple projects have attempted to foster inclusion; and to state that those interventions would be inconceivable 25 years ago.

The construction of the Guga S'Thebe Arts, Culture and Heritage Village in Langa, designed by Carin Smuts Studio Architects lasted from 1996 to 1999. It is considered an example of sustainable design and it works as a post-apartheid public building. It is an attraction point for tourists who are interested in visiting the oldest township of the city. At the same time, it gives new opportunities to the local community. Its success made possible the recent addition of the theatre, completed in 2015 (Fig. 2).

Dunoon neighbourhood is a formal housing settlement built after 1994 . Although it should represent the "rainbow nation" approach, its location, 


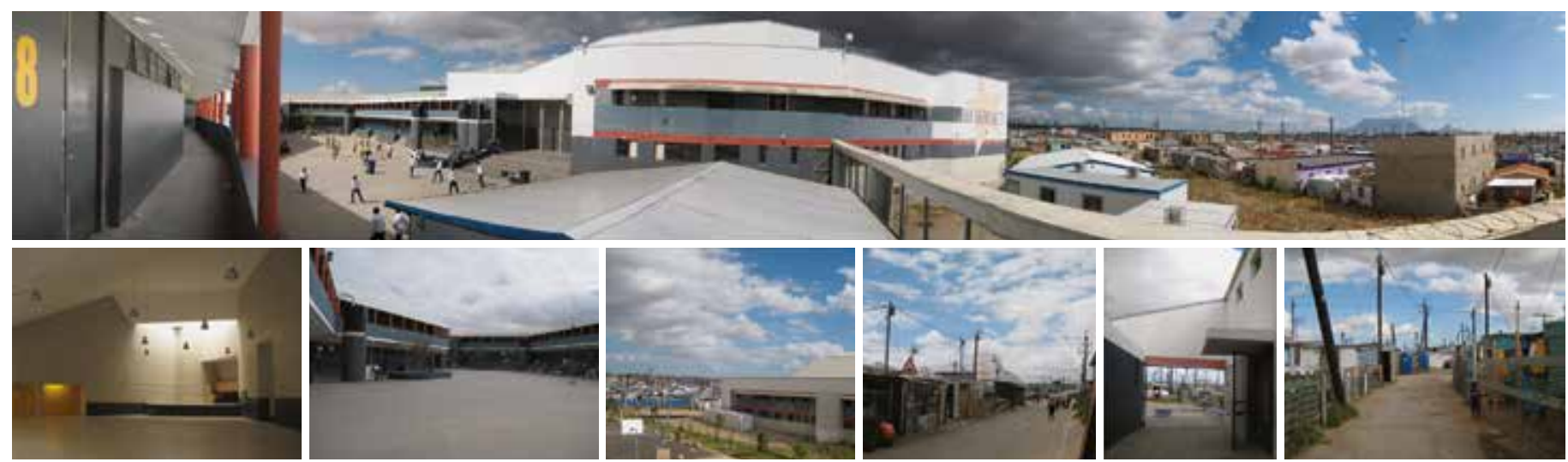

Figure 3. The panoramic view shows the contrast between the closed building of the school and the Dunoon settlement in which it is placed. The small photos show - from left to right - the interior main hall that can be used both by the school and the local community, the interior courtyard, the sport intervention next to the school, the contrast between the Dunoon street and the school's façade, the main entrance where the library is placed and a typical Dunoon street.

its poor urban planning and the lack of opportunities for inhabitants makes it look like a township. The area is composed by a mixture of small formal housing surrounded by informal expansions, commonly called "backyard shacks." Within this context the Inkwenkwezi Secondary School was commissioned by the Western Cape to Heinrich Wolff architect. The school is structured around an interior courtyard and it includes spaces that can be open to the community when the school is closed. The refined architecture stands out in the Dunoon context: it represents an unexpected opportunity for the community (Fig. 3).

Manenberg Human Settlement Contact Centre by Ashley Hemraj architect was completed in 2012. It obtained the 4 Star Green Star SA thanks to its focus on sustainability. The "eco-beam \& sand technology" is one of the construction methods used in the project. This method combines together an innovative technology with the use of simple materials. Therefore, the surrounding community can be employed and involved in the construction process (Fig. 4).

Since crime is one of the main challenges facing Cape Town - especially in township areas - it has been established a partnership between the City of Cape Town and the German Development Bank to create a programme called VPUU (Violence Prevention through Urban Upgrading). The aim of this programme is to set up a model for how to use safety as a public good to develop human potential and improve the quality of life. The first exemplary project carried out in Khayelitsha consisted of a mix of economically and socially oriented facilities. The connection between those amenities assures a safe path in Harare from the Khayelitsha station to the Luleka Primary School. A second interesting project by VPUU is the Kuyasa interchange, also in Khayelitsha township. The urban planning design strategy considers 

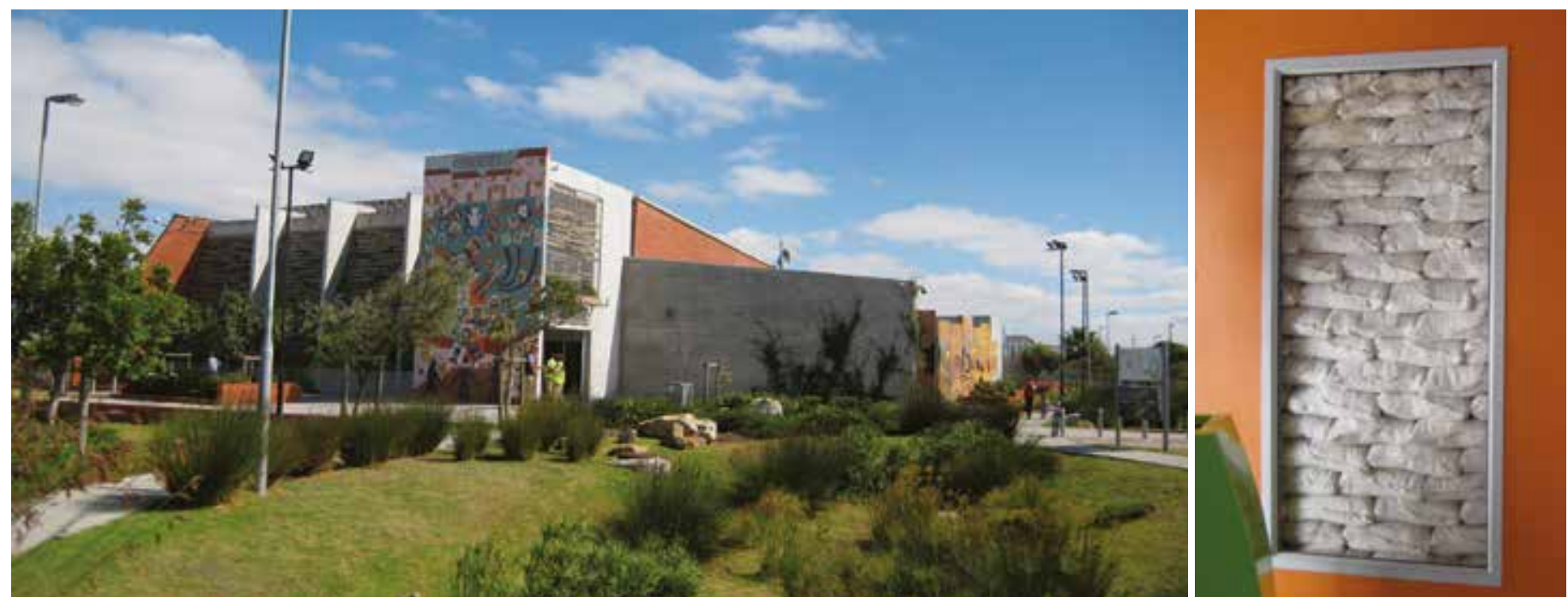

Figure 4. Photo of the Manenberg Human Settlement Contact Centre's main façade - on the left - and of the "eco-beam \& sand technology" used - on the right.

safety, integration and active surveillance as central issues to be addressed (Figs. 5-6).

Within the MyCity municipal project (Cape Town Integrated Rapid Transit - IRT - system) the SPUD department designed a skate park connected to the Garden's neighbourhood MyCity station. The vacant area below the Jutland Avenue Bridge hosts the new open-air public space since 2014. This is one of the few cases in which the City have used a waste

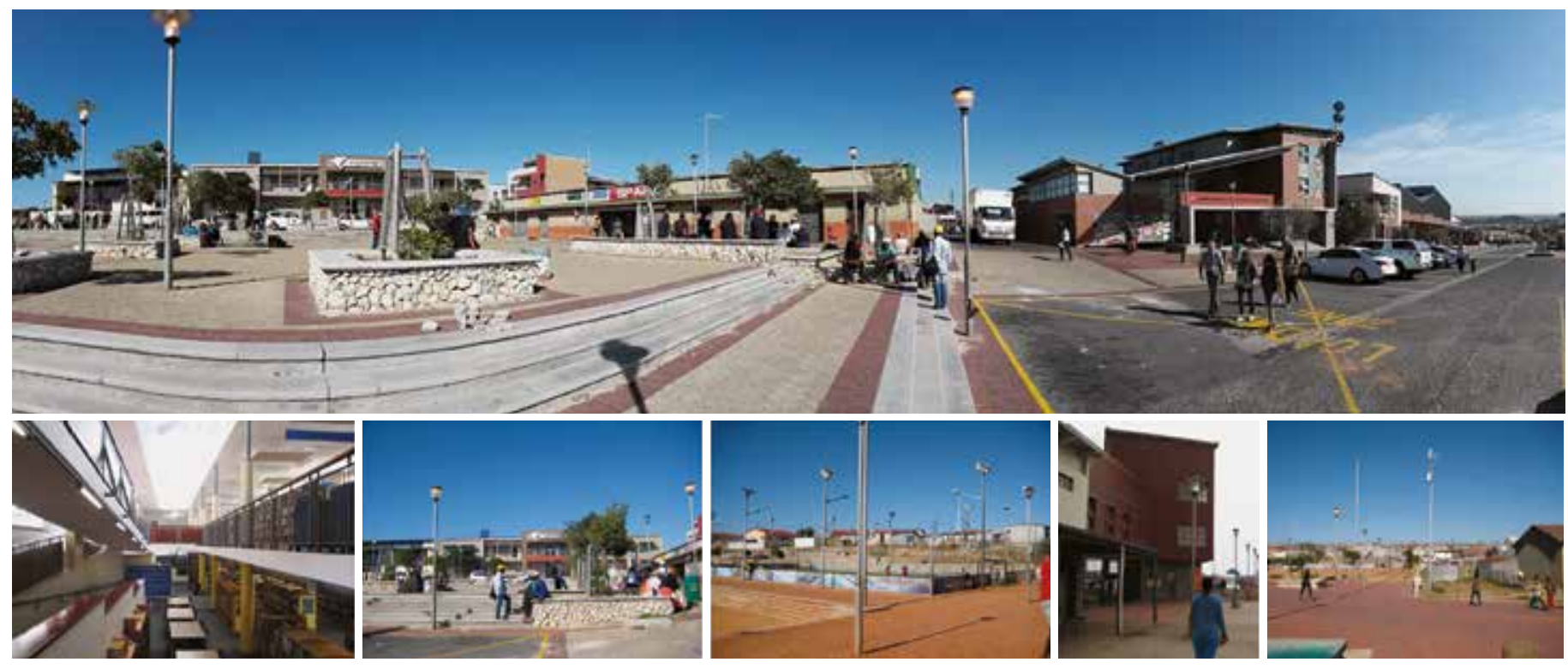

Figure 5. The panoramic photo shows Harare Square, the core of the Harare project. The small photos show - from left to right - the interior of the library, a detail of the Harare square, a soccer field space, one "Activity Box" next to the station and a portion of the Urban Park. 
piece of land for a special leisure need and to offer chances for encounter (Fig. 7).

Innovative private or NGO's project influenced the City method of planning and evaluating. As a matter of fact, the projects explained above mirror the current Municipal integrated approach. The VPUU programme set the current model used to design area-based public spaces projects. The key flagship agendas focus on:

- upgrading of informal trading areas

- attention to spaces associated with transport infrastructure

- coordination with state assisted housing areas

- informal settlement upgrading

The implementation of the integrated approach is still a great challenge within the current structure of the city. As a matter of fact, as pointed out by Cedric Daniels and others, "there is no single asset owner or line department for the public structure in its entirety, the creation of a more integrated institutional structure is required." 25

\section{CONCLUSIONS}

The discussion around spatial consequences of apartheid has been fundamental for the author (that comes from a European background) to define the framework in which the research is settled. The brief list of projects presented in the previous section gives a simple idea of various interventions done in the last two decades. Each case study would deserve a longer analysis that includes the peculiar context in which it is settled and its real impact in the local communities.

On one hand, the very peculiar context of this research prevents from any kind of generalization. On the other hand, the drastic spatial injustice visible in Cape Town reveals the need to define new ways of looking at urban spaces; to define their responsibility in creating inclusion and spatial justice in contemporary cities; and to include minorities of the society. The focus of designing should not be on symptoms of inequality and poverty, but on causes and effects that create those. The pre-1994 spatialized social inequality makes a:

meaningful improvement to black South African's lives, in terms of measure such as jobs, housing and education [...] difficult to realize. The ending of apartheid may have brought political freedom or "formal citizenship," but what James Holston identifies as "substantive citizenship" continue to elude most South Africans. ${ }^{26}$

The impact of the single project may be limited to the neighbourhood around it, but the effect of this acupuncture might be connected with other projects' influence. The aspirations of a rainbow South Africa can only be 

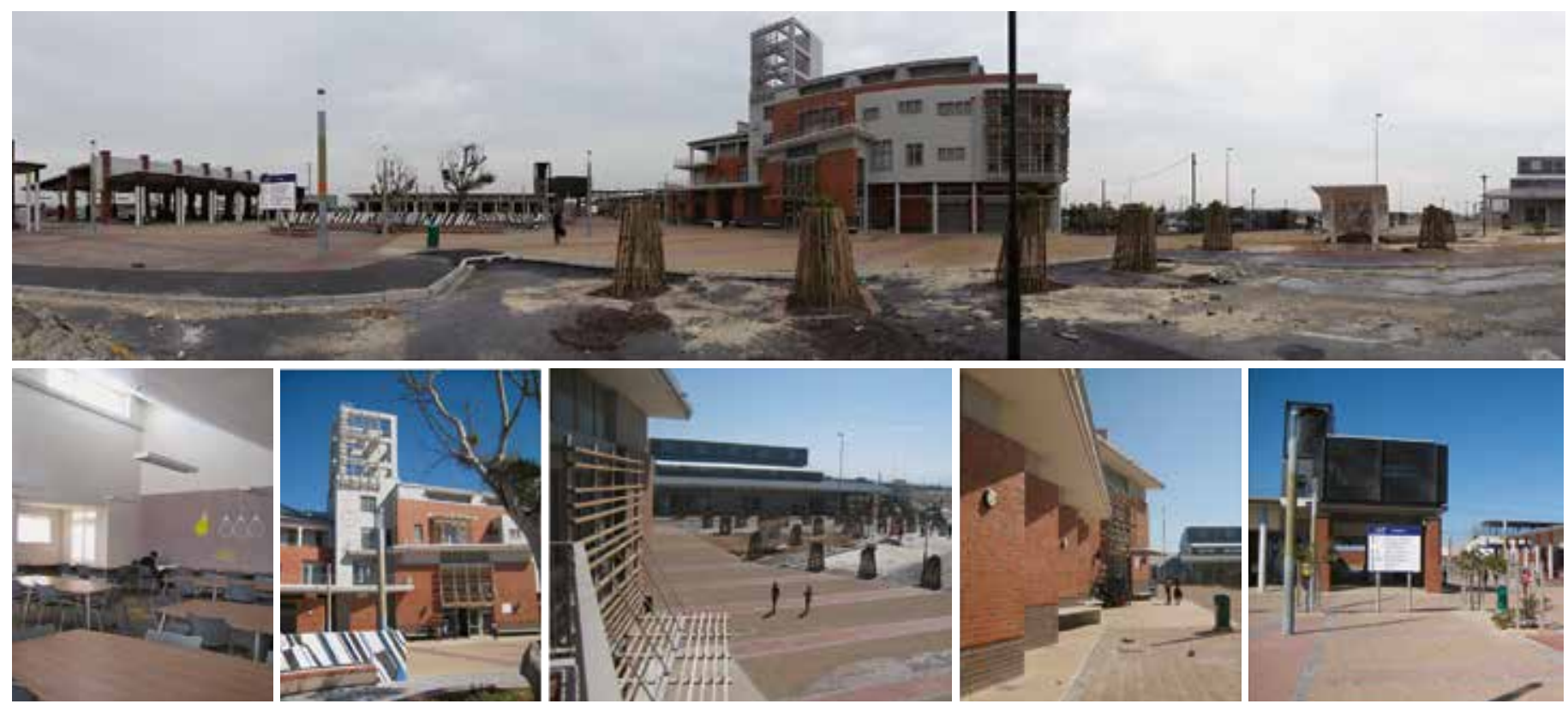

Figure 6. The panoramic photo shows the Kuyasa interchange project, with the taxi rank on the left, the station and public transportation connection in the centre and the shops and library's building on the left. The small photos show - from left to right - the interior of the library, the façade of the main building that is hosting the library on the first floor and will host economic activities on the ground floor, a view from the library's terrace towards the sport facilities on the opposite side of the street, a detail of the use of materials and the connection towards the transportation interchange.
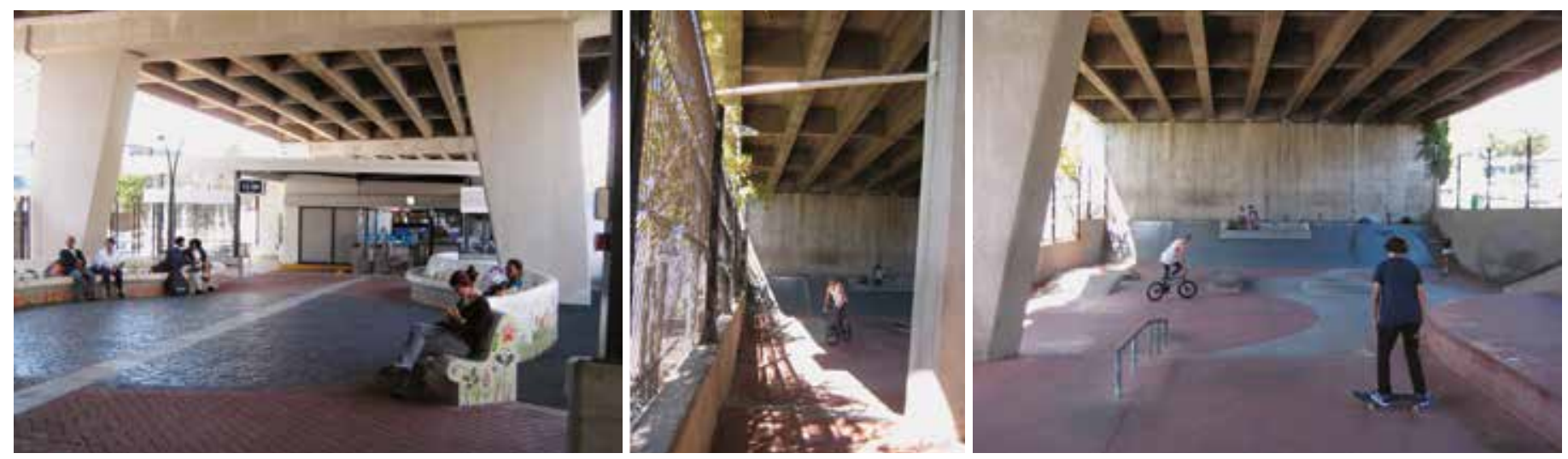

Figure 7. The photo on the left shows the Garden's MyCity station, while the other two photos show the skate park used as recreational area.

reached when a sufficient network of public interventions will balance the previous unequal distribution and their low quality.

Theoretical references to the current South African ambitions could be connected with the concept of the "right to the city" by Henri Lefebvre ${ }^{27}$ and the idea of "spatial justice" proposed by Edward Soja. ${ }^{28}$ The first notion is intended as "right to use space, right to urban life: [...] not as a 'visiting' right, nor as the right to shelter or seek refuge. This idea has the 
potential to disrupt long established paradigms of urban order and planning." ${ }^{29}$ This is the objective that Cape Town planning must pursue. Inclusion and "interracial contact has increased slowly over the past decade, although this contact varies by race, employment status and occupation." ${ }^{30}$ Therefore, some improvements are already visible. Architects, planners and scholars need to keep aspiring to equity and integration, remembering the importance of comparing, adjustment and self-criticism.

\section{Notes}

1. For more information see UN, "Sustainable Development Goals. 17 Goals to Transform Our World" http://www.un.org/sustainabledevelopment/sustainable-development-goals/.

2. Some researcher tried to link some form of "democratization" with forms of social exclusion, poverty and polarization in the Roman socio-economic model. To find out more see Pasquale De Muro, Salvatore Monni and Pasquale Tridico, "Knowledge-Based Economy and Social Exclusion: Shadow and Light in the Roman Socio-Economic Model," International Journal of Urban and Regional Research 35, no. 6 (November 2011): 1212-1238.

3. The World Bank, "Gini index data (World Bank estimate)," 1981-2014. http://data. worldbank.org/indicator/SI.POV.GINI?locations=B8\&view=map.

4. Jane Battersby-Lennard, "Apartheid/Post-Apartheid," International Encyclopedia of Human Geography, ed. Rob Kitchin and Nigel Thrift (Oxford, UK: Elsevier, 2009), 163-73 (172).

5. Kim De Readt, "Building the Rainbow Nation. A Critical Analysis of the Role of Architecture in Materializing a Post-Apartheid South African Identity," Afrika Focus 25, no. 1 (2012): 7-27.

6. For more information see Bill Freund, The African City. A History (Cambridge, UK: Cambridge University Press, 2007), 59.

7. Sharóne L. Tomer is an Assistant Professor in the School of Architecture + Design, College of Architecture \& Urban Studies, at Virginia Tech. In her current research she is examining the architectural dimensions of apartheid's ending in Cape Town. The author explains the "public space turn" into her draft work by the author titled "Cape Town. A (Re) Turn to Public Space," (unpublished manuscript, September 30, 2016): 3.

8. Battersby-Lennard, "Apartheid/Post-Apartheid," 169.

9. Tomer, "Cape Town," 6.

10. The privatization is an underway process, with different modalities. For a research around recent process of privatization of public spaces see Karina Landman, "Privatising Public Space in Post-Apartheid South African Cities Through Neighbourhood Enclosures," GeoJournal, 66, no. 1-2 (2006): 133-146.

11. Tomer, "Cape Town," 6.

12. Edgar Pieterse, "Re-Building amongst Ruins. The Pursuit of Urban Integration in South Africa (1994-2001)," (PhD dissertation, London School of Economics - University of London, March 2006), 12.

13. Bulelwa Makalima-Ngewana, "Using Public Space to Bridge Divides," January 13, 2016. http://www.capetownpartnership.co.za/2016/01/using-public-space-to-bridge-divides/.

14. Planning and Development Directorate, "City of Cape Town Municipal Spatial

Development Framework Draft," Planning and Economic Development Cluster, City of Cape Town, August 1999, 12.

15. Planning and Development Directorate, "City of Cape Town," 15.

16. For more information see Planning and Development Directorate, "City of Cape Town," 21-51.

17. David Dewar affirmed the importance of public space as "urban living rooms" in the MuniSDF in 1999 (51) and in David Dewar and Fabio Todeschini, Rethinking Urban Transport after Modernism. Lessons from South Africa (Aldershot, UK: Ashgate Publishing), 2004. 18. Myriam Houssay-Holzschuch and Emma Thébault, "Dis-locating Public Space. Occupy Rondebosch Common, Cape Town," Environment and Planning A 0, no. 0 (2015): 2. 19. David Dewar and Roelof Uytenbogaardt, South African Cities. A Manifesto for Change 
(Cape Town: Urban Problems Research Unit, University of Cape Town, 1991), 67-88.

20. For more information about Cape Town polarization see Charlotte Lemanski, "Global Cities in the South. Deepening Social and Spatial Polarization in Cape Town," Cities 24, no. 6 (2007): 448-461.

21. Lemanski, "Global Cities in the South," 459.

22. For more information see http://www.capetown.gov.za/Departments/Spatial\%20 Planning\%20and\%20Urban\%20Design\%20Department.

23. Barbara Southworth, "Urban Design in Action: The City of Cape Town's Dignified Places Programme - Implementation of New Public Spaces Towards Integration and Urban Regeneration in South Africa," Urban Design International 8, no. 3 (2003): 125.

24. Barbara Southworth, "City Squares in Cape Town's Townships - Public Space as an Instrument of Urban Transformation: The Origins, Objectives and Implementation of the City of Cape Town's Dignified Places Programme", ResearchGate (January 12, 2005): 7. https://www.researchgate.net/publication/242689030 City Squares in Cape Town\%27s Townships - Public Space as an Instrument of Urban Transformation The Origins Obiectives and Implementation_of the City of_Cape Town\%27s Dignified_Places Programme.

25. Cedric Daniels et al., "Public Structure. A Starting Point for Incremental Upgrading," in Upgrading Informal Settlement in South Africa. A Partnership Based Approach, ed. Liza Cirolia et al. (Claremont, Cape Town: University of Cape Town Press, 2016): 130-44 (139). 26. Tomer, "Cape Town," 18.

27. For more details see Henri Lefebvre, Le droit à la ville (Paris: Anthropos, 1968), English ed. Henri Lefebvre, and Eleonore Kofman and Elizabeth Lebas eds., Writings on Cities (New York: Wiley-Blackwell, 1996).

28. For more details see Edward W. Soja, Seeking Spatial Justice (Minneapolis MN, USA: University of Minnesota Press, 2010).

29. Ananya Roy is a Professor of Urban Planning and Social Welfare and Director of The Institute on Inequality and Democracy at UCLA Luskin CA, USA. She has been a professor of City and Regional Planning and Distinguished Chair in Global Poverty and Practice at the Universtity of California, Berkeley. While there, she took part on the \#GlobalPOV Project, a program of the Global Poverty and Practice (GPP) Minor, based at the Blum Center for Developing Economies, created with the intent of creating new ways of thinking about poverty and inequality. An interesting point of view about poverty is shown in this video lesson: Blum Center for Developing Economies, 2013, "Are Slums the Global Urban Future?," published on line July 31, 2013. https://www.youtube.com/watch?v=1xk7dr3VG6s. 30. Owen Crankshaw, "Urbanisation, Racial Desegregation and the Changing Character of Interracial Contact," in Re-thinking Reconciliation: Evidence from South Africa, ed. Kate Lefko-Everett et al. (Pretoria, South Africa: HSRC Press, 2017): 81-99 (97).

\section{References}

Battersby-Lennard, Jane. "Apartheid/ Post-Apartheid." International Encyclopaedia of Human Geography. Edited by Rob Kitchin and Nigel Thrift. Oxford, UK: Elsevier, 2009: 163-73.

Crankshaw, Owen. "Urbanisation, Racial Desegregation and the Changing Character of Interracial Contact." Rethinking Reconciliation: Evidence from South Africa. Edited by Kate Lefko-Everett et al. Pretoria, South Africa: HSRC Press, 2017: 81-99.

Daniels, Cedric, Liezel Kruger-Fountain, Marco Geretto, Berendine Irrgang, and Ancunel Steyn. "Public Structure. A Starting Point for Incremental Upgrading." Upgrading Informal Settlement in South Africa. A Partnership Based Approach, edited by Liza Rose Cirola, Tristan Gorgens, Miriam Van Dock, Warren Smit, and Scott Drimie. Claremont, Cape Town: University of Cape Town Press, 2016: 130-44.

De Muro, Pasquale, Salvatore Monni, and Pasquale Tridico. "Knowledge-Based Economy and Social Exclusion. Shadow and Light in the Roman Socio-Economic Model." International Journal of Urban and Regional Research 35, no. 6 (November 2011): 1212-38.

De Readt, Kim. "Building the Rainbow Nation. A Critical Analysis of the Role of Architecture 
in Materializing a Post-Apartheid South African Identity." Afrika Focus 25, no. 1 (2012): 7-27.

Dewar, David and Roelof Uytenbogaardt. South African Cities. A Manifesto for Change. Cape Town: Urban Problems Research Unit, University of Cape Town, 1991.

Dewar, David, and Fabio Todeschini. Rethinking Urban Transport after Modernism. Lessons from South Africa. Aldershot, UK: Ashgate Publishing, 2004.

Houssay-Holzschuch, Myriam, and Emma Thébault. "Dis-locating Public Space. Occupy Rondebosch Common, Cape Town." Environment and Planning A 0, no. 0 (2015): 1-17.

Freund, Bill. The African City. A History. Cambridge, UK: Cambridge University Press, 2007. Landman, Karina. "Privatising Public Space in Post-Apartheid South African Cities through Neighbourhood Enclosures." GeoJournal 66, no. 1-2 (2006): 133-146.

Lefebvre, Henri. Le droit à la ville. Paris: Anthropos, 1968. English ed. Henri Lefebvre, and Eleonore Kofman and Elizabeth Lebas eds., Writings on Cities. New York: WileyBlackwell, 1996.

Lemanski, Charlotte. "Global Cities in the South. Deepening Social and Spatial Polarization in Cape Town." Cities 24, no. 6 (2007): 448-461.

Makalima-Ngewana, Bulelwa. "Using Public Space to Bridge Divides." Cape Town Partnership, January 13, 2016. http://www.capetownpartnership.co.za/2016/01/usingpublic-space-to-bridge-divides/.

Pieterse, Edgar. "Re-Building amongst Ruins. The Pursuit of Urban Integration in South Africa (1994-2001)." PhD diss., London School of Economics - University of London, March 2006.

Planning and Development Directorate, City of Cape Town Municipal Spatial Development Framework Draft. Planning and Economic Development Cluster, City of Cape Town, 1999.

Southworth, Barbara. "Urban Design in Action: The City of Cape Town's Dignified Places Programme - Implementation of New Public Spaces Towards Integration and Urban Regeneration in South Africa." Urban Design International 8, no. 3 (2003): 119-133.

Soja, Edward W. Seeking Spatial Justice. Minneapolis MN, USA: University of Minnesota Press, 2010.

Southworth, Barbara. "City Squares in Cape Town's Townships - Public Space as an Instrument of Urban Transformation: The Origins, Objectives and Implementation of the City of Cape Town's Dignified Places Programme." ResearchGate (January 12, 2005): 7. https://www.researchgate.net/publication/242689030 City Squares in Cape Town\%27s Townships - Public Space as an Instrument of Urban Transformation The Origins Obiectives and Implementation of the City of Cape Town\%27s Dignified_Places_Programme.

\section{Credits}

Figures 1-7: photos by the Author (2016).

Miriam Bodino is an architect and a PhD candidate at the Politecnico di Torino, Italy. Her research focuses on the impact of architecture in creating inclusive spaces, taking Cape Town, South Africa as a case-study. She received her M.Arch. in 2011 discussing a thesis about upgrading processes in informal context (Dharavi, Mumbai). Her BA thesis was about the ecological footprint of buildings. She has been working as a freelance architect in Italy, Switzerland and the USA. E-mail: miriam.bodino@polito.it. 